DOI: $10.14451 / 3.40 .41$

\title{
АКТУАЛЬНЫЙ ПОДХОД К РАССМОТРЕНИЮ ИННОВАЦИЙ В ИНВЕСТИЦИОННО-СТРОИТЕЛЬНОМ КОМПЛЕКСЕ РОССИИ
}

\section{(C) 2018 Беляева Елена Юрьевна}

аспирант кафедры экономики и управления предприятиями и производственными комплексами

Санкт-Петербургский государственный экономический университет

191023, г. Санкт-Петербург, ул. Садовая, д. 21

E-mail: lenaprokopenkova@mail.ru

В статье отражены последние тенденции в инновационно-экономическом поле строительной индустрии. В частности, актуализирована цель применения инноваций и предложены принципы для достижения поставленной цели применительно к инвестиционно-строительному комплексу с теоретической стороны вопроса. Также охарактеризована практическая сторона проблемы инноваций и предложены механизмы преодоления препятствий для инвестиционно-строительного комплекса. Рекомендовано комплексное применение видов инноваций.

Ключевые слова: инвестиционно-строительный комплекс, инновации, экономический эффект, циифровизация, социальные риски.

Различные вопросы, связанные с инновациями в строительстве, рассмотрены в работах российских учёных: Алексеева А.А. [1], Асаула А.Н. [2], Полякова Е.К. [3], Соколовой С.А. [4], Страховой А.С. [5] и др.; зарубежных исследователей: Bock T. [11], Czarnecki L. [12], Meng X. [13], Shibeika A. [14], Sinem Mollaoglu [15], и др.

Актуальность вопроса инноваций в инвестиционно-строительном комплексе (далее - ИСК) также подтверждается анализом научной литературы [10], проведенным автором по ключевым фразам «инновации в строительстве» и «строительные инновации»: в сумме было выявлено 1649 работ за период 2010-2017 гг. С уверенностью можно заявить, что интерес к теме инноваций в строительной отрасли с каждым годом

возрастает - это отражает линия тренда на рисунке 1.

Подходы к определению инноваций в ИСК изменялись наряду с общим определением. Действительно, подход выделения инноваций лишь как научно-технического прогресса устарел, и на сегодняшний день фокус исследователей направлен на изучение инноваций по видам, т.е. маркетингового, процессного, продуктового, организационного характера.

На современном этапе, безусловно, инновация направлена не только на научно-технический, но и на экономический, и социальный эффекты. Данный подход поддерживается и руководством Осло [16], однако автор считает необходимым дополнить применение инноваций

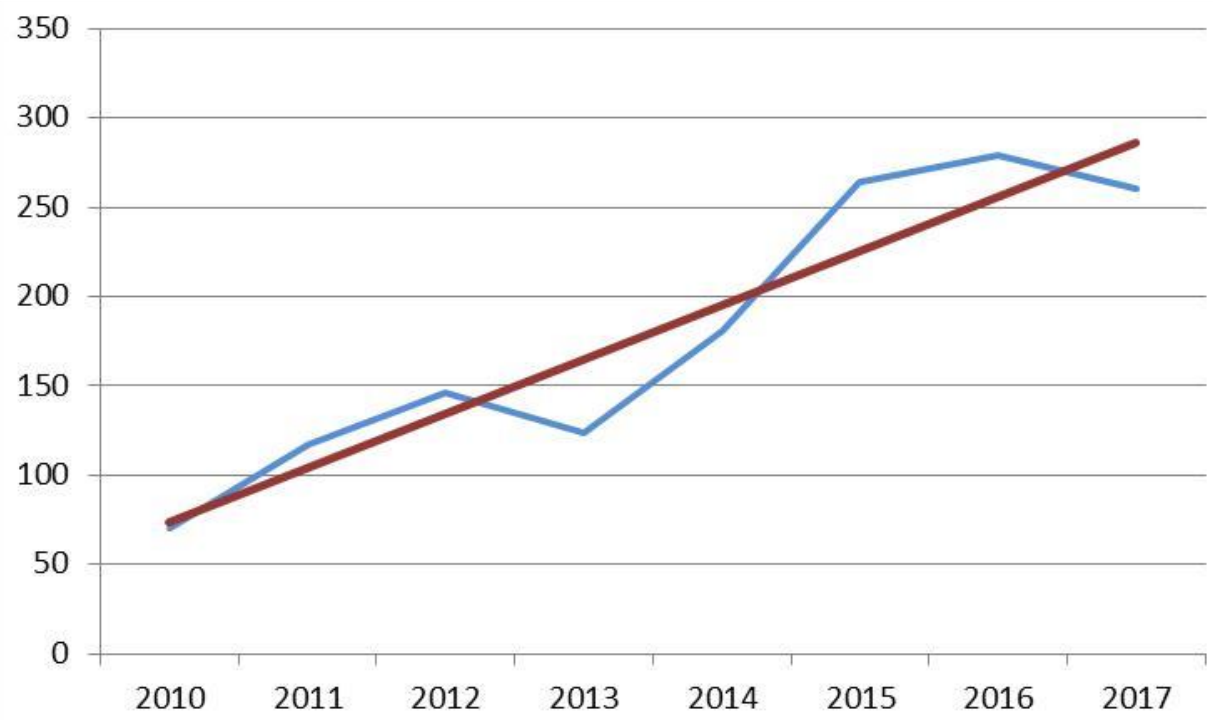

Puc. 1. График тенденции исследования инноваций в строительстве 
в направлении охраны окружающей среды, выделяя тем самым экологический эффект.

Основная цель инноваций заключается в получении полезного эффекта и устойчивого развития комплекса в целом. Данная цель может быть достигнута за счет соблюдения следующих принципов:

1. Принцип научно-технического прогресса, который заключается в традиционной инновации (улучшении и усовершенствовании продукта или технологии).

2. Принцип экономической эффективности (применяемые инновации должны быть экономически обоснованы и их использование должно приносить прибыль).

3. Принцип экологичности (является актуальным, поскольку согласно природоохранному законодательству необходимо соблюдать законодательно-правовые рамки в части нормирования выбросов загрязняющих веществ в воздушное пространство, в водные ресурсы, земельные ресурсы и недра).

4. Социальный принции (инновации в плане организации работы помогают создавать новые группы взаимодействия людей, что нацелено на более успешное внедрение инновации и развитие общества в целом).

Инновации в инвестиционно-строительном комплексе должны носить взаимодействующий характер, так как полезный эффект от их применения при этом будет повышаться. Определённо, при осуществлении лишь продуктовой инновации её эффективность без применения других видов инноваций (маркетинговой, процессной, организационной) не будет максимальна. Данный подход возникает из зарубежного опыта

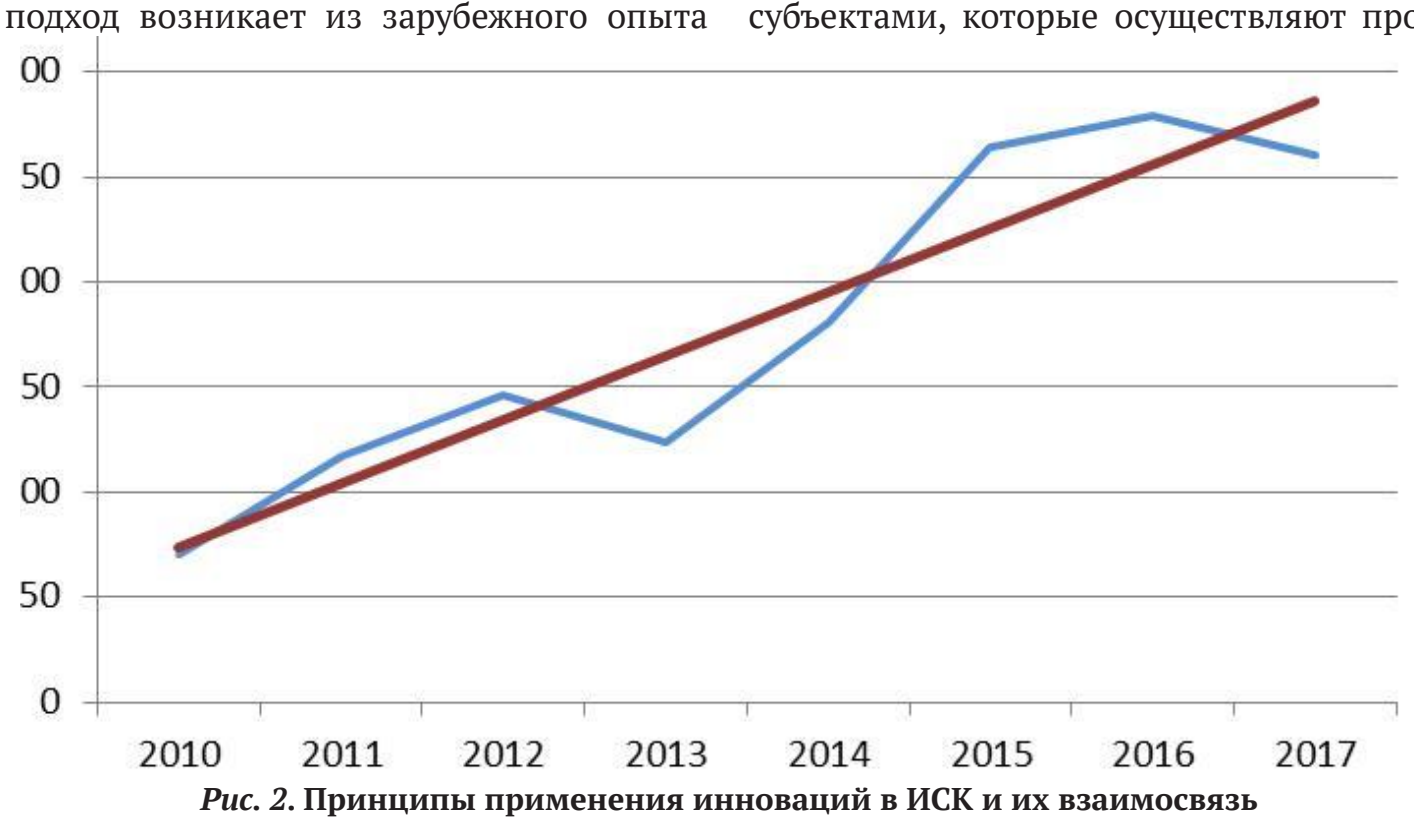

применения инноваций [16]. На рисунке 2 графически отражена взаимосвязь инноваций в ИСК и принципов их применения.

С практической стороны вопроса, проблема инноваций в инвестиционно-строительном комплексе России стоит особенно остро. Согласно указу Президента [8] необходимо не только увеличить темпы ввода жилых объектов в 1,76 раза (с 79,2 $\mathrm{m}^{2}$ [9] до $140 \mathrm{~m}^{2}$ ), но и создавать новое качество жилья. Данная задача может быть выполнена за счёт комплексного выполнения мер по внедрению инноваций. Существующие проблемы и разработанные автором предложения для достижения данной цели представлены в табл.

Все вышеперечисленные проблемы приводят к удлинению процесса создания или реконструкции строительного продукта (здания или сооружения) и увеличивают потери в виде транзакционных издержек.

K ключевым современным проблемам автор относит не завершенный этап цифровизации, медленное внедрение инноваций в повседневную практику, отсутствие активного интереса к моделям СІМ-моделирования. Цифровизацию на сегодняшний день необходимо рассматривать как механизм решения проблем взаимодействия поставщиков, застройщиков и потребителей - своевременное и прозрачное информационное поле позволит снизить негативные эффекты.

Существуют и другие барьеры, которые замедляют введение инноваций в ИСК. К ним автор относит социальные риски: несработанность коллектива, отсутствие взаимопонимания между субъектами, которые осуществляют проектную 
Таблица. Проблемы внедрения инноваций в ИСК и возможные пути решения

\begin{tabular}{|c|c|c|}
\hline Проблема и ее расшифровка & Предложения автора & Ответственные субъекты ИСК \\
\hline \multicolumn{3}{|c|}{ Продуктовые и процессные инновации } \\
\hline $\begin{array}{l}\text { Медленное внедрение инноваций } \\
\text { в повседневную практику: лишь } \\
\text { 8,8\% обследованных организаций } \\
\text { внедрили данный вид инноваций } \\
\text { [7] }\end{array}$ & $\begin{array}{l}\text { Увеличение затрат на инновации; } \\
\text { Создание отделов по разработке и } \\
\text { внедрению инноваций для ускоре- } \\
\text { ния адаптации технологии; } \\
\text { Адаптация зарубежного опыта; } \\
\text { Активное использование систем } \\
\text { «нового проектирования»: } \\
\text { ВІМ - информационное модели- } \\
\text { рование проекта (экономическая и } \\
\text { техническая составляющие); } \\
\text { СІМ - полное моделирование гра- } \\
\text { достроительной ситуации }\end{array}$ & $\begin{array}{l}\text { Решение проблемы лежит на стро- } \\
\text { ительной организации: } \\
\text { - Проектные бюро } \\
\text { - Подрядчики } \\
\text { - Застройщики } \\
\text { - Технические заказчики } \\
\text { - Поставщики }\end{array}$ \\
\hline $\begin{array}{l}\text { - полное отсутствие у 20,9\% [6] } \\
\text { населения России (пользователей } \\
\text { объектов недвижимости) возмож- } \\
\text { ностей использования технологии } \\
\text { Интернет }\end{array}$ & \multirow[t]{3}{*}{$\begin{array}{l}\text { Завершение первого этапа цифро- } \\
\text { визации для городов России; }\end{array}$} & \multirow[t]{3}{*}{$\begin{array}{l}\text { Решение данного вопроса на- } \\
\text { ходится в функционале испол- } \\
\text { нительной власти субъектов РФ } \\
\text { (департаментов и министерств) }\end{array}$} \\
\hline $\begin{array}{l}\text { - доступ к сервисам и услугам } \\
\text { (ЖКХ, сервис «Госуслуги» и др.) }\end{array}$ & & \\
\hline $\begin{array}{l}\text { - поиск актуальной информации } \\
\text { для приобретения качественного } \\
\text { жилья (реестр застройщиков) для } \\
\text { покупателей объектов недвижи- } \\
\text { мости }\end{array}$ & & \\
\hline $\begin{array}{l}\text { Низкий уровень производства } \\
\text { инновационных материалов }(5,3 \%) \\
\text { [9] }\end{array}$ & $\begin{array}{l}\text { Модернизация производств: } \\
\text { переход на выпуск новых матери- } \\
\text { алов (быстровозводимые блоки, } \\
\text { «умные» материалы: бетон, кир- } \\
\text { пич и др.) }\end{array}$ & Производители материалов \\
\hline \multicolumn{3}{|c|}{ Организационные инновации } \\
\hline $\begin{array}{l}\text { 2,8\% организаций используют ор- } \\
\text { ганизационные инновации [7] } \\
\text { Устаревшие формы и методы } \\
\text { управления проектом, несоответ- } \\
\text { ствующие современным реалиям, } \\
\text { приводят к удорожанию материа- } \\
\text { лов, работ и услуг, а также прино- } \\
\text { сят сверхнормативные временные } \\
\text { потери }\end{array}$ & $\begin{array}{l}\text { Повышение способности компа- } \\
\text { ний к заимствованию и адаптации } \\
\text { технологий; } \\
\text { Адаптация зарубежного опыта; }\end{array}$ & $\begin{array}{l}\text { Руководители организаций, заня- } \\
\text { тых в строительстве }\end{array}$ \\
\hline \multicolumn{3}{|c|}{ Маркетинговые инновации } \\
\hline $\begin{array}{l}\text { Являются инструментом продаж } \\
\text { и оказания услуг. Низкий уровень } \\
\text { развитости данного вида иннова- } \\
\text { ций (1,7\% компаний применяют } \\
\text { данные инновации [7]) приводит к } \\
\text { снижению интереса покупателей } \\
\text { объектов недвижимости }\end{array}$ & $\begin{array}{l}\text { Использование новых методов } \\
\text { продаж, способов сотрудничества } \\
\text { и рекламного продвижения }\end{array}$ & $\begin{array}{l}\text { Служба маркетинга строительных } \\
\text { организаций }\end{array}$ \\
\hline
\end{tabular}

работу. Также необходимо отметить и другие факторы, ограничивающие внедрение инноваций в ИСК: низкую потребность строительного рынка в инновациях, низкую рыночную конкуренцию между предприятиями, недостаток хороших идей, фокус строительных предприятий лишь на продуктовых инновациях (материалах для проведения строительно-монтажных работ), отсутствие стимулов для внедрения инноваций в строительную индустрию.

Дефицит инноваций и неверное их внедрение в строительной отрасли приводит к экономическим потерям на всех уровнях - отрасли, комплекса, отдельной фирмы. Таксономический расчёт потерь производится в каждом отдельном случае индивидуально и носит довольно трудоёмкий характер. 


\section{Библиографический список}

1. Алексеев А.А. Механизм технологических инноваций в строительстве // Экономические науки. 2015. № 10(131). С. 73-76.

2. Асаул А.Н. Инновации в инвестиционно-строительной сфере: учеб. пособие для академического бакалавриата / А.Н. Асаул, М.А. Асаул, Д.А. Заварин, Е.И. Рыбнов; под ред. А.Н. Асаула. Москва. 2017. 207 с.

3. Поляков Е.К. Обоснование внедрения единой системы диспетчеризации и регулировании инженерными сетями при управлении и эксплуатации зданий и сооружений /Е.К. Поляков, П.Г. Грабовый// Экономика и предпринимательство. 2018. № 1(90). С. 1085-1089.

4. Соколова С.А. Применение инновационного модульного строительства в пригородных зонах/ С.А. Соколова [и др.] // Экономика и предпринимательство. 2016. № 8 (73). С. 950-954.

5. Страхова А.С. Инновационные технологии в строительстве как ресурс экономического развития и фактор модернизации экономики строительства /А.С. Страхова, В.А. Унежева// Вестник Белгородского государственного технического университета им. В.Г. Шухова. 2016. № 6. С. 263-272.

6. Исследование НИУ «Высшая школа экономики» и «Яндекс. Такси»: «Цифровизация в малых и средних городах России», 2018. Презентация. URL: https://www.hse.ru/data/2018/06/06/1149766040/2018-06-GSU-HSE_ pres_v6.pdf (дата обращения: 19.10.2018) 